\title{
Phenotypic Variability of MEGF10 Variants Causing Congenital Myopathy: Report of Two Unrelated Patients from a Highly Consanguineous Population
}

\author{
Mohammad AlMuhaizea ${ }^{1,+} \oplus$, Omar Dabbagh ${ }^{1,+}$, Hanan AlQudairy ${ }^{2,+}$, Aljouhra AlHargan $2, \ddagger$, Wafa Alotaibi $1, \ddagger$, \\ Ruba Sami ${ }^{1}$, Rahaf AlOtaibi ${ }^{1}$, Mariam Mahmoud Ali ${ }^{1}$, Hindi AlHindi ${ }^{3}$, Dilek Colak ${ }^{4}$ (I) and Namik Kaya ${ }^{2, *}$ (D) \\ 1 Neuroscience Center, King Faisal Specialist Hospital and Research Center, Riyadh 11211, Saudi Arabia; \\ mmuhaizea@kfshrc.edu.sa (M.A.); ODABBAGH@kfshrc.edu.sa (O.D.); wafaasattam@gmail.com (W.A.); \\ ruba.sami@hotmail.com (R.S.); rahoofa788@gmail.com (R.A.); dr.mariam999@gmail.com (M.M.A.) \\ 2 Department of Translational Genomics, Center for Genomic Medicine, KFSHRC, Riyadh 11211, Saudi Arabia; \\ halqudairy@kfshrc.edu.sa (H.A.); aljouhra.hargan@gmail.com (A.A.) \\ 3 Department of Pathology and Laboratory Medicine, KFSHRC, Riyadh 11211, Saudi Arabia; \\ HAL-hindi@kfshrc.edu.sa \\ 4 Department of Biostatistics, Epidemiology and Scientific Computing, KFSHRC, Riyadh 11211, Saudi Arabia; \\ dkcolak@gmail.com \\ * Correspondence: nkaya@kfshrc.edu.sa; Tel.: +966-11-464-7272 (ext. 39612) \\ + Equal contribution. \\ $\ddagger$ Equal contribution.
}

Citation: AlMuhaizea, M.; Dabbagh, O.; AlQudairy, H.; AlHargan, A.; Alotaibi, W.; Sami, R.; AlOtaibi, R.; Ali, M.M.; AlHindi, H.; Colak, D.; et al. Phenotypic Variability of MEGF10 Variants Causing Congenital Myopathy: Report of Two Unrelated Patients from a Highly Consanguineous Population. Genes 2021, 12, 1783. https://doi.org/ 10.3390/genes12111783

Academic Editor: Fabio Coppedè

Received: 20 October 2021

Accepted: 4 November 2021

Published: 10 November 2021

Publisher's Note: MDPI stays neutral with regard to jurisdictional claims in published maps and institutional affiliations.

Copyright: () 2021 by the authors. Licensee MDPI, Basel, Switzerland. This article is an open access article distributed under the terms and conditions of the Creative Commons Attribution (CC BY) license (https:// creativecommons.org/licenses/by/ $4.0 /)$.
Abstract: Congenital myopathies are rare neuromuscular hereditary disorders that manifest at birth or during infancy and usually appear with muscle weakness and hypotonia. One of such disorders, early-onset myopathy, areflexia, respiratory distress, and dysphagia (EMARDD, OMIM: 614399, MIM: 612453), is a rare autosomal recessive disorder caused by biallelic mutations (at homozygous or compound heterozygous status) in MEGF10 (multiple epidermal growth factor-like domains protein family). Here, we report two unrelated patients, who were born to consanguineous parents, having two novel MEGF10 deleterious variants. Interestingly, the presence of MEGF10 associated EMARDD has not been reported in Saudi Arabia, a highly consanguineous population. Moreover, both variants lead to a different phenotypic onset of mild and severe types. Our work expands phenotypic features of the disease and provides an opportunity for genetic counseling to the inflicted families.

Keywords: MEGF10; congenital myopathy; novel variants; splicing; convex scoliosis; butterfly vertebrae; atelectasis; bronchiectasis; flexion deformity; subluxation

\section{Introduction}

Congenital myopathies (CMs) are rare inherited conditions with a broad phenotypic and genetic diversity. CMs manifest after birth or during infancy with static or slowly progressive clinical course [1]. Despite their phenotypic diversity, patients demonstrate common symptoms, including hypotonia, muscle weakness, dysmorphic features, and respiratory insufficiency [2-4]. Based on the histological features of muscle biopsy, CMs are classified into five main types: nemaline myopathies, core myopathies, centronuclear myopathies (CNM), congenital fiber-type disproportion, and myosin storage myopathies, where each is further divided into different subtypes [4,5]. Rod-like inclusions in muscle biopsy characterize nemaline myopathies while cores in muscle biopsy distinguish core myopathies from the other types. Central core disease (CCD) and multiminicore disease $(\mathrm{MmD})$ (core myopathies) are the most common form of congenital myopathies. Various mutations in 27 different genes have been linked to CMs and they may cause the same disease phenotype $[1,4,6]$. On the other hand, different mutations in the same gene may result in various types of CMs [7]. 
In 2011, Logan et al., reported the first MEGF10 mutation associated with CMs [8]. MEGF10 encodes a transmembrane receptor belong to multiple epidermal growth factorlike domains protein family. It is expressed in the central nervous system (CNS) predominantly in the brain, astrocytes, and satellite cells of skeletal muscle. The receptor has a critical role in mediating apoptosis during cell phagocytosis by binding to phosphatidylserine expressed on the surface of apoptotic cells [9]; hence, it involves in cell adhesion, motility, proliferation, and phagocytosis through macrophages and astrocytes of apoptotic cells. Satellite cells work as a precursor of muscle cells. In normal cases, satellite cells are inactive in resting muscles. During exercise, trauma, or muscle injury, these cells become activated and MEGF10 is upregulated to produce myogenic cells, which differentiate into new muscle fibers and fuse with existing fibers. This explains satellite cells' depletion in MEGF10 associated congenital myopathies [8]. MEGF10 that is located on the long arm of chromosome 5q23.2. Currently, there are several reported mutations in MEGF10 including small deletions and insertions, various missense, nonsense, splicing, and a large gross deletion that expands 757 base pairs spanning over exon 7 . These mutations have been reported to cause autosomal recessive congenital myopathy, areflexia, respiratory distress, and dysphagia with early or late-onset syndrome [10,11] (abbreviated as EMARDD, OMIM: 614399, MIM: 612453), minicore myopathy [9,12,13], and limb girdle muscular dystrophy [14,15], and muscle weakness [16]. Missense, frameshift indels, and nonsense mutations in MEGF10 cause respiratory distress usually induced by diaphragmatic paralysis. Affected individuals frequently become ventilator dependent or die secondary to respiratory failure [17].

This study reports two unrelated Saudi patients with mild and severe congenital myopathy due to two different novel variants in MEGF10. These are the first two patients to be reported in Saudi Arabia, reflecting the possibility of under-recognized cases in the Gulf region, where autosomal recessive conditions prevail due to the consanguinity [18].

\section{Materials and Methods}

\subsection{Patients and Ethics}

Two boys from two separate unrelated families were included to the project. The parents in each family are first-degree cousins. The patients were presented to our institution (King Faisal Specialist Hospital and Research Center, KFSHRC) with variable degrees of hypotonia and weakness for investigation and carefully examined by board-certified pediatric neurologists at the neuroscience clinics in the hospital (Table 1) family pedigrees are presented in Figure 1. After obtaining the signed informed consents (approved by institutional review board, Research Advisory Council at Office of Research Affairs at KFSRCH, RAC\#2120022), blood samples (5 mL for each individual) from the patients and unaffected family members were collected into EDTA tubes. To establish EBV transformed lymphoblastoid cell lines, additional blood samples from probands were collected into heparin tubes $(3 \mathrm{~mL})$. 
Table 1. Patients' clinical and genetic features.

\begin{tabular}{|c|c|c|}
\hline Patients & Patient 1 & Patient 2 \\
\hline Muscle Biopsy & Unremarkable. & Not done \\
\hline Clinical Features & $\begin{array}{l}\text { Plagiocephaly, forehead ridge and hirsutism, down } \\
\text { slanting eyes, epicanthal folds, mild bilateral ptosis, } \\
\text { symmetric facial weakness, low set ears with backward } \\
\text { rotation, high arched palate, long fingers, camptodactyly } \\
\text { of ring and middle fingers, pectus excavatus, low hair line, } \\
\text { sacral dimple in the lower back and scoliosis, areflexia }\end{array}$ & $\begin{array}{l}\text { Plagiocephaly, symmetric myopathic facies, } \\
\text { high arched palate, low set ears, scoliosis, } \\
\text { generalized hypotonia, areflexia }\end{array}$ \\
\hline Outcome & Death due to respiratory infection. & $\begin{array}{l}\text { Survival (patient is currently alive, last visit } \\
\text { was at age of } 9 \text { years old) }\end{array}$ \\
\hline Brain MRI & Mild bilateral frontalatrophic changes & Not done \\
\hline EMG & $\begin{array}{c}\text { Myopathic changes in tibialis anterior and vastus lateralis } \\
\text { muscles }\end{array}$ & Neurogenic changes \\
\hline Genotype & MEGF10:c.3132dupA:p.Glu1045Argfs*22:homozygous & $\begin{array}{l}\text { NM-032446.2:c. } 2980+5 \text { G>C:Splice site } \\
\text { variant, homozygous }\end{array}$ \\
\hline $\mathrm{O}_{2}$ req. & NC., 1-2L & None \\
\hline Dysphagia & Gastronomy tube feeding (Severe dysphagia) & Oral (Mild oral dysphagia) \\
\hline Best motor ability & Non-sitting & Ambulant \\
\hline Onset of Symptoms & Since birth & Since birth \\
\hline
\end{tabular}

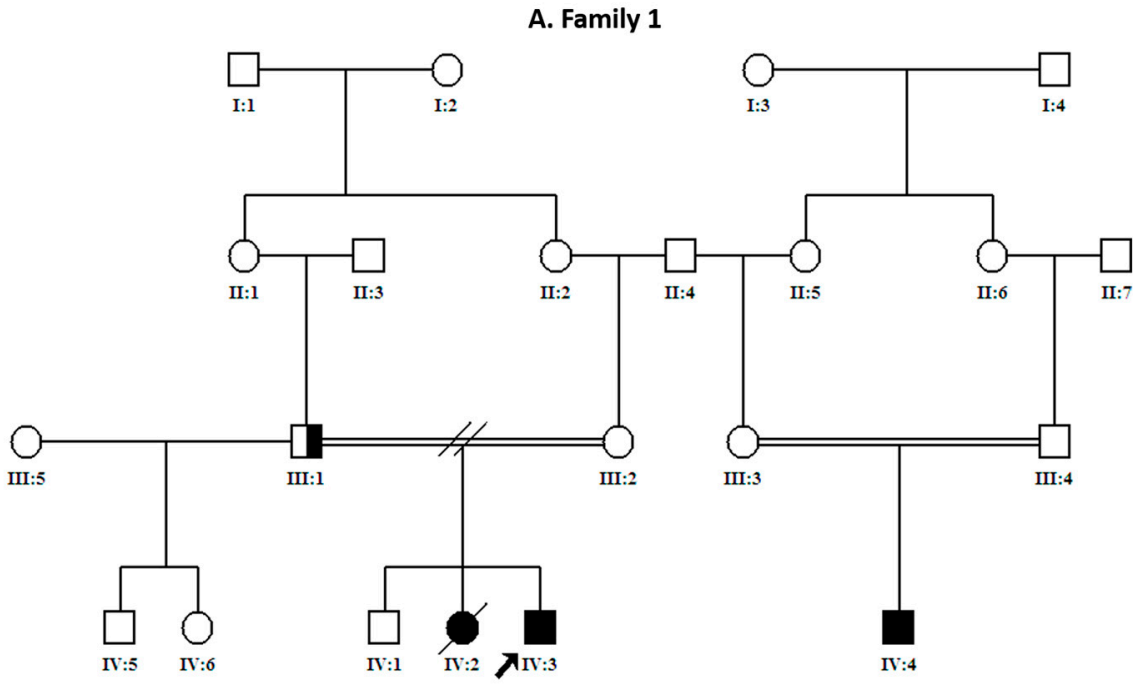

B. Family 2

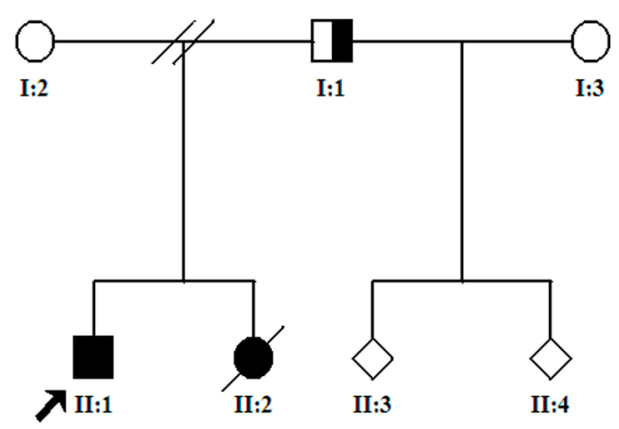

Figure 1. Family pedigrees indicating affected members. (A) Extended pedigree of the first family shows two branches of Table 2. IV3, and IV4). Among the patients, only the index case was genetically tested. (B) Pedigree of the second family shows two affected siblings in the family. 


\subsection{DNA Extraction}

DNA isolation was carried out using commercially available kits according to the manufacturer's instruction (Gentra Systems, Minneapolis, MN, USA). DNA quality and quantity were checked using Nanodrop instrument (ND-1000) (Thermo Fisher Scientific Corp., Waltham, MA, USA) and stored at $-20{ }^{\circ} \mathrm{C}$ for further use such as next generation sequencing and Sanger sequencing reactions.

\subsection{Gene Panel Screening, Variant Detection, and Sanger Sequencing}

A comprehensive gene panel consisting of numerous genes and mutations (Supplementary Table S1) were designed and used on Ion Torrent Proton sequencing platform according to manufacturer's guidelines (Thermo Fisher Scientific Corp.). Briefly, the reads were processed by the Torrent Suite Software and variant annotation web server using Ion Reporter Software (Thermo Fisher Scientific Corp.). Identified variants filtered and confirmed by Sanger Sequencing according to standard protocols.

\section{4. $R T-P C R$}

To investigate the impact of the splice site variant on the transcript, RNA extracted from the lymphoblastoid cell lines from the patient 2. First, cDNA was synthesized using High-Capacity cDNA Reverse Transcription Kit (Thermo Fisher Scientific Corp.) using random hexamers. Then MEGF10-specific primers designed to include the variant site and likely skipped regions were utilized during the amplification of the cDNA. RT-PCR products were analyzed on $2 \%$ agarose gel.

\section{Results}

3.1. Clinical Findings

\subsubsection{Patient 1 (Family 1)}

A consanguineous Saudi family with a six-months-old boy was referred to our institution (KFHSRC) from a local hospital. The boy was suffering from congenital progressive hypotonia with a significant family history. He has two older siblings, a healthy five-yearold brother and a sister with a similar disease presentation who died at 11 months of age. The family history was free from any other CNS or metabolic disorders. The index patient was the product of a full-term pregnancy that was associated with decreased fetal movements and normal amniotic fluids. He was delivered by cesarean section due to breech presentation with a birth weight of $2.9 \mathrm{~kg}$. Due to significant hypotonia, dysmorphic features, he was hospitalized at a local rural hospital for 17 days. Early in the neonatal period, his mother noted abnormal movements in the form of jerky movements of upper limbs and lower jaw lasting several minutes with no associated up-rolling of eyes nor change in level of consciousness. A dramatic response to phenobarbital was observed with complete resolution of the seizures. An electroencephalogram (EEG) at four months of age at his local hospital revealed generalized epileptiform discharges. A follow up EEG at 6 months of age revealed complete resolution of these discharges. He had two chest infections requiring hospital admission.

The six-month-old child showed developmental delay upon examination, and his growth parameters were at a rate below the 3rd percentile (weight: $3.7 \mathrm{~kg}$, length: $57 \mathrm{~cm}$, and head circumference: $38.5 \mathrm{~cm}$ ). He was dysmorphic with evidence of plagiocephaly, forehead ridging, and hirsutism with down slanting eyes, epicanthal folds, mild bilateral ptosis, facial diplegia, low set posteriorly rotated ears, high arched palate, low hairline, long fingers, camptodactyly of the ring and middle fingers, pectus excavatum, and a sacral dimple in the lower back with a hair tuft and scoliosis. The tongue was in the midline with no evidence of fasciculations. Severe hypotonia was noted, with significant head lag and inability to sit while supported. His deep tendon reflexes were absent. He had a weak cry and cough. His general examination revealed no skin, cardiovascular, or genital abnormalities or organomegaly. He had a good social smile. He had good regard for his 
own hands. He could reach and transfer objects. His extraocular movement was normal, with equally reactive pupils.

Spinal Magnetic resonance imaging (MRI) revealed scoliosis and right diaphragmatic eventration. At age of four months, a brain MRI was carried out and showed mild bifrontal atrophy changes. A skeletal muscle biopsy of the right thigh was essentially normal and showed minimal variation in myofiber size (Figure 2A) and unremarkable endomysial connective tissue. There were no inclusions or vacuoles, and the intermyofibrillar network is intact. There was only a mild nonspecific subsarcolemmal mitochondrial proliferation (Figure 2B) and a mild increase in stainable lipids (Figure 2C). Unfortunately, the patient passed away at the age of eight months secondary to respiratory failure following a severe chest infection. His affected sister presented to a local hospital with early life severe hypotonia, muscle weakness, dysphagia, oxygen dependency, and dysmorphic features, but no definite diagnosis was established at the time. She died at the age of 11 months due to respiratory failure.
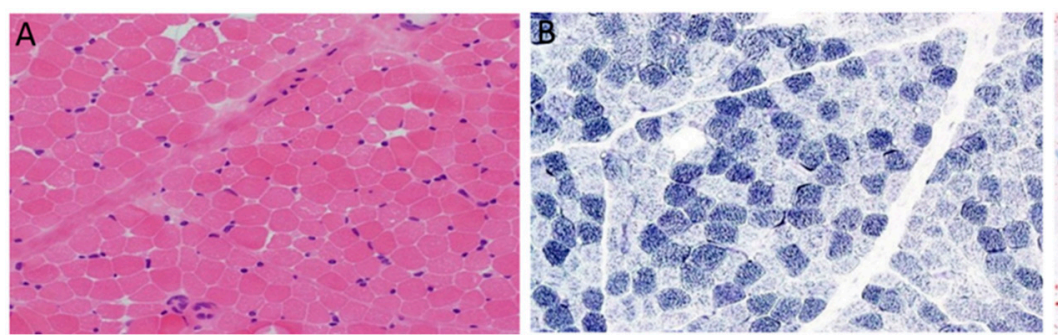

D

Family 1

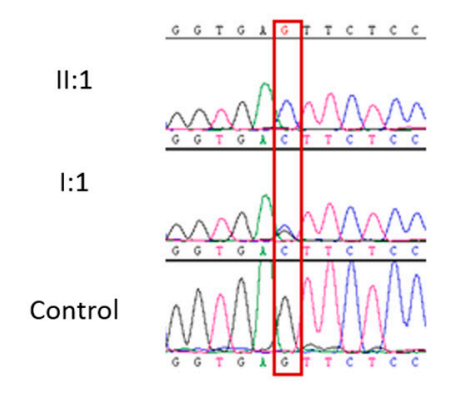

NM_001256545.2: Exon21:c.2980+5G>C

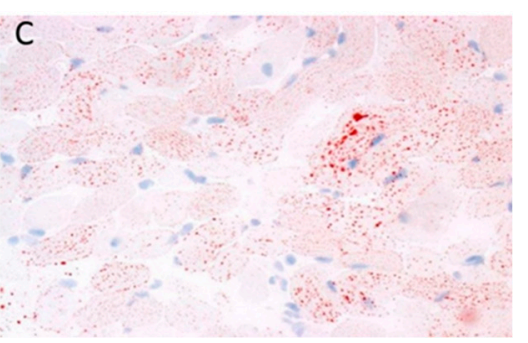

Family 2

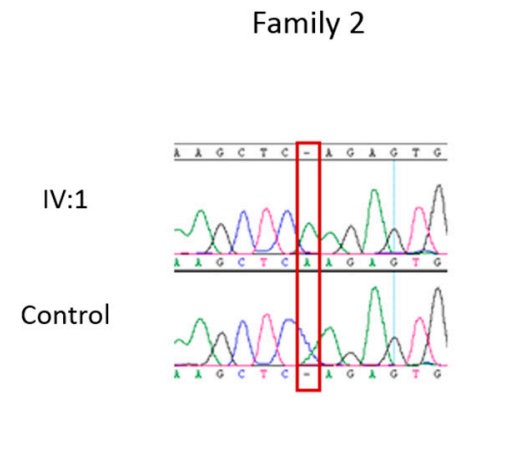

Figure 2. Histopathological and genetic findings. (A) H\&E: Rare small fibers. (B) NADH: increased subsarcolemmal activity in some fibers. (C): Oil Red O stain: increase in intracellular lipid. (D) The image displays the chromatogram of the index patients (IV: 3 and II: 1 in each family) harboring the variants (c.3132dupA), (c.2980+5G>C), respectively.

Nerve conduction study (NCS) was unremarkable. Electromyography showed myopathic changes in the tibialis anterior and vastus lateralis muscles. His skeletal survey revealed mild right convex scoliosis in the dorsal spine and butterfly vertebrae in the dorsal and lumber vertebra (Figure $3 \mathrm{~A}-\mathrm{C}$ ). Flexion deformity in the fingers is noted, especially the ring and middle fingers of both hands involves the proximal interphalangeal joints (Figure 3D,E). Elevation of the right hemidiaphragm is noted with atelectasis in the right lower lobe and bronchiectasis in both lower lobes with average heart size (Figure 3F). There is left developmental dysplasia of the hip (Figure 3G) and hypoplasia of the proximal phalanx of the left big toe with subluxation of the left first metatarsophalangeal joints on the left side (Figure $3 \mathrm{H}$ ). Renal ultrasound revealed bilateral nephrolithiasis. 

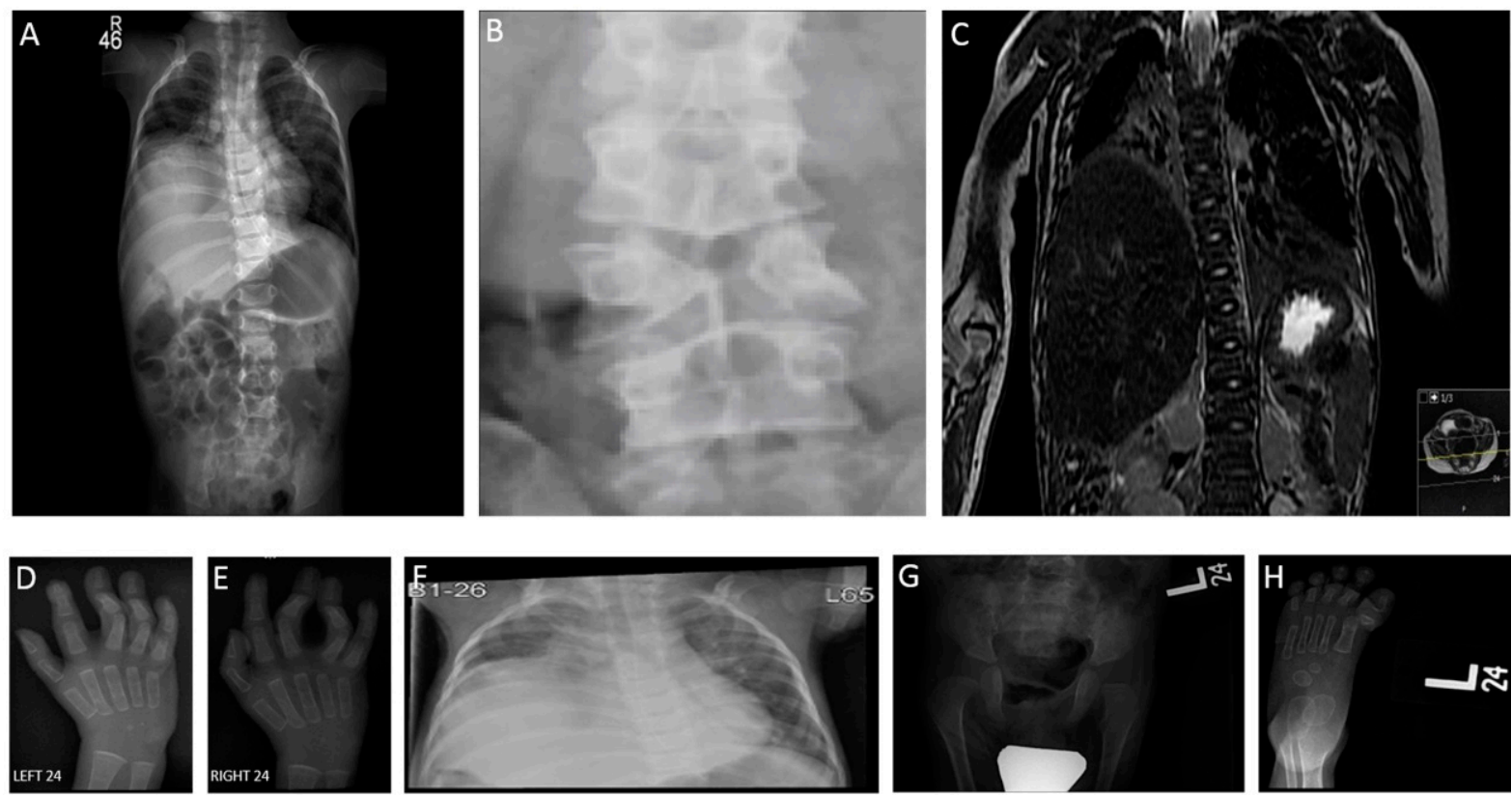

Figure 3. Radiological demonstration of deformities in patient 1. (A) Mild right convex scoliosis in the dorsal spine. (B) Butterfly vertebrae in the dorsal and lumber vertebra. (C) Mild right convex scoliosis in the dorsal spine. (D,E) Flexion deformity in the fingers especially the ring and middle fingers of both hands involve the proximal interphalangeal joints. (F) Elevation of the right hemidiaphragm is noted with atelectasis in the right lower lobe and bronchiectasis in both lower lobes. Heart size is normal (G) Subluxation of the left hip joint. (H) Hypoplasia of the proximal phalanx of the left big toe with subluxation of the first metatarsophalangeal joint on the left side. Very small muscles in both lower limbs. Bilateral geno valgum more on the left side with flexion of the left knee joint.

\subsubsection{Patient 2 (Family 2)}

A four-year-old boy from a consanguineous Saudi family (first-degree cousins) presented with neonatal-onset generalized hypotonia. The pregnancy was complicated by decreased fetal movements. He had one sister with a similar phenotype who passed away at the age of 18 months with respiratory infections. His two paternal half-siblings are healthy. The patient suffered from feeding difficulties, intermittent choking, and recurrent aspiration pneumonia. In addition, significant motor developmental delay was evident early on. At 21 months, he achieved good head control, was able to sit without support, and started to crawl and reach for objects. His last clinical follow up was at the age of 9 years when he was noted to be walking independently, but was a slow runner. He was able to draw a line and completely undress himself. He engaged in-group play and had no major cognitive deficits. He did not require long-term oxygen support.

The patient was conscious and interactive during the examination. His vital signs were stable, and the oxygen concentration was well maintained on room air. He had dysmorphic features in the form of plagiocephaly, facial diplegia, high arched palate, low set posteriorly rotated ears, mild dextro convexity scoliosis of the thoracic spine with spine rigidity. Generalized hypotonia, axial more than appendicular, as well as generalized weakness (proximal more than distal) were noted. He had a positive Gower sign but no calf muscle hypertrophy. His deep tendon reflexes were absent. He also had joint hyperlaxity of knees, wrists, and elbows. A detailed neurometabolic workup, inclusive of blood lactic and pyruvic acids, ammonia, biotinidase, tandem mass spectroscopy, urine gas chromatography and mass spectroscopy, creatine kinase, as well as thyroid function, were all normal. Nerve conduction studies (NCS) was unremarkable while EMG of the vastus lateralis muscle showed neurogenic changes more suggestive of motor neuron disease. A modified barium study showed mild oral dysphagia. Echocardiogram showed trivial pulmonary valve regurgitation with normal biventricular systolic function. 


\subsection{Genetic Analysis}

Gene testing for spinal muscular atrophy was negative for the patient 1 . Highresolution cytogenetic evaluation based on SNP arrays did not detect any definite chromosomal abnormality or pathogenic copy number variant (CNV). A comprehensive myopathy gene panel for patient 1 revealed a homozygous variant in MEGF10 (NM_032446.2:c.3132dupA:p.Glu1045Argfs*22) (Figure 2D). DNA analysis for patient 2 for myotonic dystrophy $(D M P K)$ was unremarkable. For patient 2, comprehensive muscular dystrophy and myopathy gene panel revealed a splicing variant in MEGF10 (NM_032446.2:c.2980+5G>C:Exon21:Chr5:126784919) (Figures 2D and 4A-C). In addition to this biallelic splice site variant, the panel revealed another pathogenic variant of PRKAG3 (c.364dupA, p.Thr122Asnfs*11) at heteroallelic state.

A

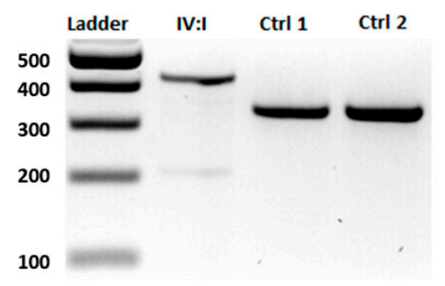

B

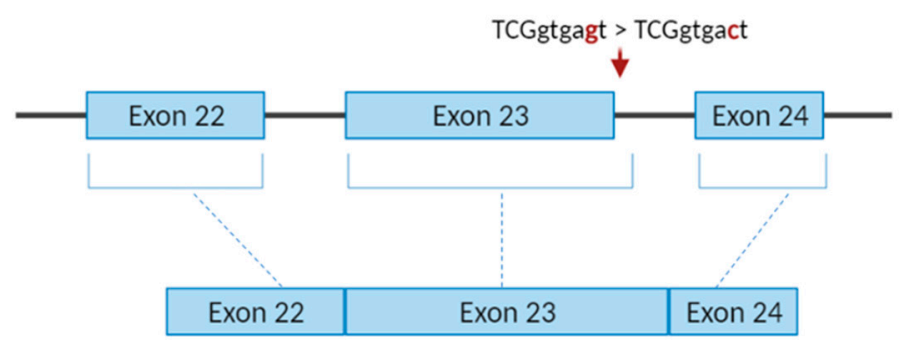

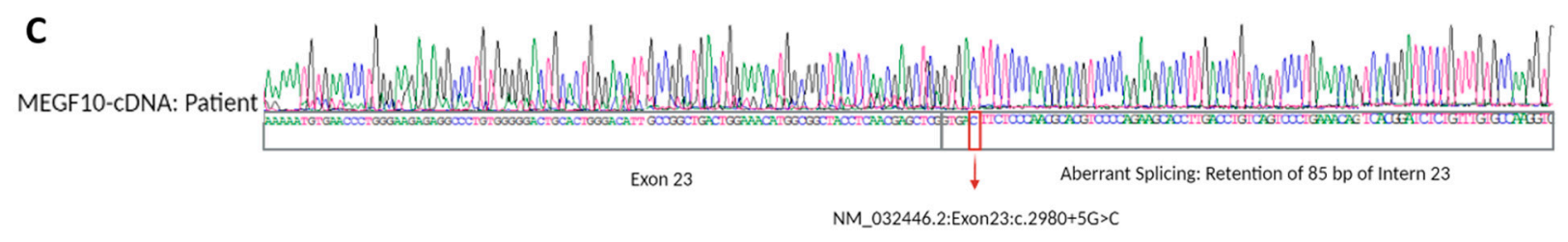

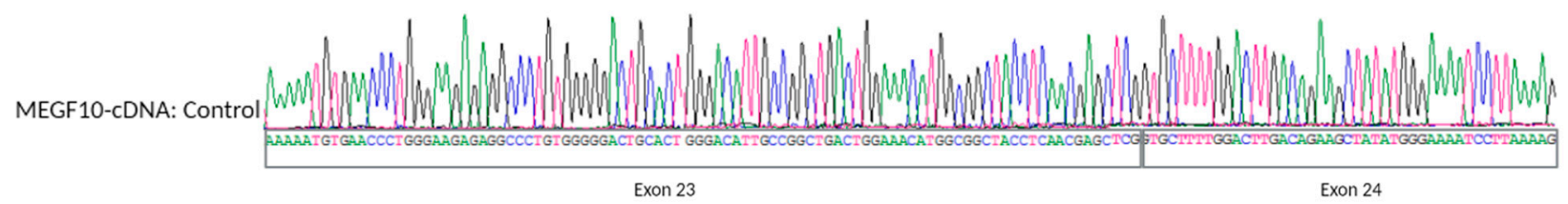

Figure 4. RT-PCR result for patient 2. RT-PCR was performed on RNA extracted from lymphocytic cell culture line from the patient 2 followed by $2 \%$ agarose gel electrophoresis. (A) Compared to both controls, the patient has a higher size band implicating presence of an aberrant transcript. (B) Illustration presents the predicted splicing effect. (C) A variant at the fifth nucleotide in intron 23 was found by DNA Sanger sequencing that is also indicated presence of a retained DNA ( $85 \mathrm{bp}$ ) from intron 23.

RT-PCR on patient's 2 RNA revealed presence of a larger fragment in the patient's sample in comparison to those of the controls (Figure 4A). The larger fragment was purified from the gel. Sanger sequencing analysis of the abnormal RT-PCR product showed retention of $85 \mathrm{bp}$ from the intron 23, resulting in a larger aberrant transcript (Figure 4C).

\section{Discussion}

EMARDD is considered an autosomal recessive congenital myopathy characterized by early-onset at birth, or during infancy. The disease is characterized by areflexia and respiratory distress caused by diaphragmatic weakness or paralysis [1]. With progression of the disease, respiratory failure necessitates long term respiratory support, with subsequent demise of nearly half of the patients. Additional features include dysphagia often requiring gastrostomy feeding, generalized muscle weakness causing delayed motor development, poor head control, facial weakness, cleft palate, contractures, and scoliosis [12,19]. In severe cases, most patients never achieve walking [13,14]. EMARDD and MmD share some phenotypic features. There are several mutations reported in MEGF10 that causes 
different onset (Table 2). Only a few reported MmD cases were caused by a MEGF10 mutation. However, half of the reported MmD cases are caused by mutations in SEPN1 and RYR1 genes [12]. Moreover, MmD caused by MEGF10 mutations is considered a mild form of EMARDD with early or late onset of symptoms [13]. All MEGF10-related MmD cases are caused by compound heterozygous missense mutations except for two cases. One had a single heterozygous missense (c.211C > T) and the other had splicing mutation (c.2981-2A>G). This can explain late onset of $\mathrm{MmD}$ in some of the cases where residual MEGF10 prevents the development of early-onset respiratory muscle weakness [12]. Most EMARDD patients had homozygous nonsense, missense mutations, and small indels except for one patient who had a compound heterozygous mutation (a missense change (c.2320T>C), and a small deletion (c.1325delC). Therefore, it is reasonable to think that in most cases EMARDD is linked to stop codon mutations $[8,12,13,20]$.

Table 2. List of previously reported pathogenic variants in MEGF10 found in the literature.

\begin{tabular}{|c|c|c|c|c|c|c|}
\hline No. & $\begin{array}{l}\text { Variant Name } \\
\text { (cDNA) }\end{array}$ & Variant Type & $\begin{array}{l}\text { Variant Name } \\
\text { (Amino Acid) }\end{array}$ & $\begin{array}{l}\text { Phenotypic } \\
\text { Details }\end{array}$ & Ethnicity & References \\
\hline 1 & c. $211 \mathrm{C}>\mathrm{T}$ & Missense & p.R71W & $\begin{array}{l}\text { Minicore } \\
\text { myopathy }\end{array}$ & Portuguese & $\begin{array}{c}\text { Boyden (2012) } \\
\text { Neurogenetics 13, } 115 \text { [9] }\end{array}$ \\
\hline 2 & c. $230 \mathrm{G}>\mathrm{A}$ & Missense & p.R77Q & $\begin{array}{l}\text { Minicore } \\
\text { myopathy }\end{array}$ & $\begin{array}{l}\text { French- } \\
\text { F/German-M }\end{array}$ & $\begin{array}{c}\text { Liewluck (2016) Muscle } \\
\text { Nerve 53, } 984 \text { [12] }\end{array}$ \\
\hline 3 & c. $352 \mathrm{~T}>\mathrm{C}$ & Missense & p.C118R & $\begin{array}{c}\text { Muscular } \\
\text { dystrophy, limb } \\
\text { girdle }\end{array}$ & Unknown & $\begin{array}{l}\text { Harris (2017) Orphanet J } \\
\quad \text { Rare Dis 12, } 151 \text { [15] }\end{array}$ \\
\hline 4 & c. $352 \mathrm{~T}>\mathrm{C}$ & Missense & p.C118R & $\begin{array}{l}\text { Muscular } \\
\text { dystrophy, limb } \\
\text { girdle }\end{array}$ & Unknown & $\begin{array}{c}\text { Harris (2018) } \\
\text { Neuromuscul Disord 28: } \\
48 \text { [14] }\end{array}$ \\
\hline 5 & c. $976 \mathrm{~T}>\mathrm{C}$ & Missense & p.C326R & $\begin{array}{l}\text { Minicore } \\
\text { myopathy }\end{array}$ & $\begin{array}{l}\text { Mixed } \\
\text { European } \\
\text { Origin }\end{array}$ & $\begin{array}{c}\text { Boyden (2012) } \\
\text { Neurogenetics 13, } 115 \text { [9] }\end{array}$ \\
\hline 6 & c. $1559 \mathrm{G}>\mathrm{A}$ & Nonsense & p.W520* & EMARDD & Sri Lankan & $\begin{array}{c}\text { Logan (2011) Nat Genet } \\
43,1189 \text { [8] }\end{array}$ \\
\hline 7 & c. $1833 \mathrm{~T}>\mathrm{G}$ & Missense & p.C611W & $\begin{array}{l}\text { Minicore } \\
\text { myopathy }\end{array}$ & $\begin{array}{c}\text { French- } \\
\text { F/German-M }\end{array}$ & $\begin{array}{l}\text { Liewluck }(2016) \text { Muscle } \\
\text { Nerve 53, } 984[12]\end{array}$ \\
\hline 8 & c. $2211 G>A$ & Nonsense & p.W737* & $\begin{array}{l}\text { Muscle } \\
\text { weakness }\end{array}$ & $\begin{array}{l}\text { Canadian/Not } \\
\text { Specified }\end{array}$ & $\begin{array}{l}\text { Wu (2018) Can J Neurol } \\
\text { Sci epub, epub [16] }\end{array}$ \\
\hline 9 & c. $2301 \mathrm{C}>\mathrm{A}$ & Nonsense & p.C767* & EMARDD & Qatari & $\begin{array}{c}\text { Logan }(2011) \text { Nat Genet } \\
43,1189[8]\end{array}$ \\
\hline 10 & c. $2320 \mathrm{~T}>\mathrm{C}$ & Missense & p.C774R & EMARDD & English & $\begin{array}{c}\text { Logan (2011) Nat Genet } \\
43,1189[8]\end{array}$ \\
\hline 11 & c. $2320 \mathrm{~T}>\mathrm{C}$ & Missense & p.C774R & EMARDD & $\begin{array}{l}\text { Mixed } \\
\text { European } \\
\text { ancestry }\end{array}$ & $\begin{array}{c}\text { Boyden (2012) } \\
\text { Neurogenetics 13: } 115 \text { [9] }\end{array}$ \\
\hline 12 & c. $2429 \mathrm{G}>\mathrm{A}$ & Missense & p.C810Y & $\begin{array}{l}\text { Minicore } \\
\text { myopathy }\end{array}$ & Japanese & $\begin{array}{c}\text { Takayama (2016) } \\
\text { Neuromuscul Disord 26, } \\
604 \text { [13] }\end{array}$ \\
\hline 13 & c. $3144 \mathrm{~T}>\mathrm{G}$ & Nonsense & p.Y1048* & EMARDD & Turkish & $\begin{array}{c}\text { Logan }(2011) \text { Nat Genet } \\
43,1189[8]\end{array}$ \\
\hline 14 & c. $1426+1 G>T$ & Splicing error & - & $\begin{array}{c}\text { Muscular } \\
\text { dystrophy, limb } \\
\text { girdle }\end{array}$ & Unknown & $\begin{array}{l}\text { Harris (2017) Orphanet J } \\
\text { Rare Dis 12, } 151 \text { [15] }\end{array}$ \\
\hline 15 & c. $1426+1 G>T$ & Splicing error & - & $\begin{array}{l}\text { Muscular } \\
\text { dystrophy, limb } \\
\text { girdle }\end{array}$ & Unknown & $\begin{array}{c}\text { Harris (2018) } \\
\text { Neuromuscul Disord 28: } \\
48[14]\end{array}$ \\
\hline
\end{tabular}


Table 2. Cont.

\begin{tabular}{|c|c|c|c|c|c|c|}
\hline No. & $\begin{array}{l}\text { Variant Name } \\
\text { (cDNA) }\end{array}$ & Variant Type & $\begin{array}{l}\text { Variant Name } \\
\text { (Amino Acid) }\end{array}$ & $\begin{array}{l}\text { Phenotypic } \\
\text { Details }\end{array}$ & Ethnicity & References \\
\hline 16 & c. $2981-2 A>G$ & Splicing error & - & $\begin{array}{l}\text { Minicore } \\
\text { myopathy }\end{array}$ & Japanese & $\begin{array}{c}\text { Takayama (2016) } \\
\text { Neuromuscul Disord 26, } \\
604 \text { [13] }\end{array}$ \\
\hline 17 & c. $2980+5 G>C$ & Splicing error & - & EMARDD & Saudi & $\begin{array}{c}\text { THIS STUDY } \\
\text { Takavama }(2014)\end{array}$ \\
\hline 18 & c.131_132delTG & Small deletion & - & EMARDD & Japanese & $\begin{array}{c}\text { Neuromuscul Disord } 24 \\
848[21]\end{array}$ \\
\hline 19 & c.131_132delTG & Small deletion & - & EMARDD & Japanese & $\begin{array}{c}\text { Takayama (2016) } \\
\text { Neuromuscul Disord 26: } \\
604 \text { [13] }\end{array}$ \\
\hline 20 & c.1325delC & Small deletion & p.Pro $442 \mathrm{Hfs}^{* 9}$ & EMARDD & English & $\begin{array}{c}\text { Logan (2011) Nat Genet } \\
43,1189[8]\end{array}$ \\
\hline 21 & c.1557delA & Small deletion & p.Trp520fs* & $\begin{array}{l}\text { Myopathy, } \\
\text { areflexia, } \\
\text { respiratory } \\
\text { distress, and } \\
\text { dysphagia }\end{array}$ & $\begin{array}{l}\text { Unkown } \\
(\mathrm{M}+\mathrm{P})\end{array}$ & $\begin{array}{l}\text { Posey (2017) N Engl J } \\
\text { Med 376, } 21 \text { [22] }\end{array}$ \\
\hline 22 & c.1557delA & Small deletion & p.Trp520fs* & $\begin{array}{l}\text { Myopathy, } \\
\text { areflexia, } \\
\text { respiratory } \\
\text { distress, and } \\
\text { dysphagia }\end{array}$ & Emarati & $\begin{array}{l}\text { Alabdullatif (2017) Clin } \\
\text { Genet 91: } 616 \text { [23] }\end{array}$ \\
\hline 23 & c.2288_2297dup10 & Small insertion & p.Asp766EfsX4 & EMARDD & Pakistani & $\begin{array}{c}\text { Logan (2011) Nat Genet } \\
43,1189[23]\end{array}$ \\
\hline 24 & c.3132dupA & Small insertion & - & EMARDD & Saudi & THIS STUDY \\
\hline 25 & $\mathrm{~N} / \mathrm{A}$ & $\begin{array}{l}\text { Large deletion } \\
\text { (757 bp in exon } 7)\end{array}$ & - & EMARDD & Arab & $\begin{array}{c}\text { Pierson (2013) } \\
\text { Neuromuscul Disord 23, } \\
483[20]\end{array}$ \\
\hline 26 & c. $2320 \mathrm{~T}>\mathrm{C}$ & Missense & p.C774R & EMARDD & Unknown & $\begin{array}{l}\text { Saha et al, Hum Mol } \\
\text { Genet } 2019 \text { [24] }\end{array}$ \\
\hline 27 & c. $918-2 \mathrm{~A}>\mathrm{G}$ & Splicing error & - & EMARDD & Unknown & $\begin{array}{l}\text { Saha et al, Hum Mol } \\
\text { Genet } 2019 \text { [24] }\end{array}$ \\
\hline 28 & c. $976 \mathrm{~T}>\mathrm{C}$ & Missense & p.C326R & EMARDD & Unknown & $\begin{array}{l}\text { Saha et al, Hum Mol } \\
\text { Genet } 2019 \text { [24] }\end{array}$ \\
\hline 29 & c. $211 \mathrm{C}>\mathrm{T}$ & Missense & p.T1030C & $\begin{array}{l}\text { MEGF10 } \\
\text { myopathy, } \\
\text { adult onset }\end{array}$ & Unknown & $\begin{array}{l}\text { Saha et al, Hum Mol } \\
\text { Genet } 2019 \text { [24] }\end{array}$ \\
\hline
\end{tabular}

Here, we describe two pediatric patients in details. Both presented with hypotonia, dysmorphic features, and absent deep tendon reflexes. The 6-month-old boy had a severe phenotype presentation that caused several facial and skeletal features to be altered. As with most of the reported cases, he passed away in the first year of life due to respiratory failure. The 4-year-old boy presented with a milder phenotype. He is alive and his symptoms are milder, including dysphagia, scoliosis, and slower physical abilities compared to his peers. His phenotype is more of axial predominant myopathy with scoliosis and spine rigidity. Unfortunately, muscle histopathology could not be obtained from the milder phenotype to compare to the severe phenotype and correlated this with the EMG variability found in both cases.

Though most of the affected patients were symptomatic during early childhood, there are reports of adult presentations, who survived till their early sixties. The older cases represented a milder phenotype characterized by juvenile-onset scoliosis likely due to axial myopathy, adult-onset respiratory insufficiency, and limb muscle weakness. Joint hyperlaxity was also observed $[1,12,13]$. While most muscle biopsies of EMARDD patients show fiber size variation and adipose tissue infiltration $[8,13]$, muscle biopsy of patient 1 showed minimal changes in fiber size. 
The phenotype of EMARDD, particularly the early onset of diaphragmatic paralysis, is similar to spinal muscular atrophy with respiratory distress type (SMARD) [25]. The SMARD is an autosomal recessive disease caused by a mutation in the immunoglobulin $\mu$-binding protein 2 gene (IGHMBP2) and SMN1 [25,26]. It is a form of spinal muscular atrophy with phenotypic and genetic heterogeneity. The main difference between EMARDD and SMARD is the nervous system involvement. EMARDD has mainly myopathic features whereas SMARD is a neuromyopathic disease where patients suffer from the degeneration of the peripheral nerves, including the sensory and autonomic nerves, and frequently the distal muscles are the most affected. Therefore, it is desirable to make accurate differential diagnoses between various forms of SMARD and other congenital neuromuscular conditions presenting with diaphragmatic weakness [8]. As the disease varies in its presentation from milder to more severe forms, awareness of the phenotypes must be raised. This includes family counseling since consanguineous unions play a role in recessive genetic mutations manifestations $[5,11,27]$.

\section{Conclusions}

In conclusion, this report is the first to describe the clinical presentation of two patients with two novel variants in MEGF10 in Saudi Arabia. The phenotypic similarities between EMARDD and other congenital neuromuscular disorders such as SMARD may cause difficulties in reaching a definite diagnosis in the severe phenotype while the milder phenotype may be similar to axial predominant myopathies. Screening for dysphagia, diaphragmatic weakness and respiratory hypoventilation are important elements particularly in the milder phenotype.

Supplementary Materials: Supplementary Table. List of all genes included in the comprehensive muscular dystrophy and myopathy gene panel used to identify the pathogenic variant is available online at https:/ / www.mdpi.com/article/10.3390/genes12111783/s1, Table S1: List of previously reported pathogenic variants in MEGF10.

Author Contributions: N.K. conceived and designed the experiments. A.A., H.A. (Hanan AlQudairy), R.S. and R.A. performed the experiments; H.A. (Hindi AlHindi) oversee the pathology related experiments and data analysis. N.K. and D.C., analyzed the data. M.A., H.A. (Hanan AlQudairy), N.K., D.C., O.D., W.A. and A.A., wrote the initial draft. M.A., O.D., M.M.A., collected specimen, handled biopsies, undertook patient care and management, collected clinical data and delineated patients' phenotype. W.A., H.A. (Hanan AlQudairy) and M.A. reviewed the charts and revised the clinical descriptions. M.A., D.C., H.A. (Hanan AlQudairy) and N.K. revised the manuscript. All authors have read and agreed to the published version of the manuscript.

Funding: This research received funds from National Plan for Science, Technology, and Innovation program, King Abdulaziz City for Science and Technology (KACST), (KACST Grant Fund \#14MED2007-20 for Namik Kaya).

Institutional Review Board Statement: The study was conducted according to the guidelines of the Declaration of Helsinki, and approved by the Institutional Review Board of King Faisal Specialist Hospital and Research Center, Riyadh, Saudi Arabia (RAC\#2120022).

Informed Consent Statement: Informed consent was obtained from all subjects involved in the study.

Data Availability Statement: Not applicable.

Acknowledgments: We are grateful to the patients and families for their participation to our study. We wish to thank King Abdulaziz City for Science and Technology (NSTIP/KACST, Project\#14MED2007-20) for the generous support for Namik Kaya. We extend our thanks to Genotyping and Sequencing Core Facilities at Genetics Department at the Research Center and Saudi Human Genome Program. We thank to Research Advisory Council Committees, and Purchasing Department in KFSHRC.

Conflicts of Interest: The authors declare no conflict of interest. 


\section{References}

1. North, K.N.; Wang, C.H.; Clarke, N.; Jungbluth, H.; Vainzof, M.; Dowling, J.J.; Amburgey, K.; Quijano-Roy, S.; Beggs, A.H.; Sewry, C.; et al. Approach to the diagnosis of congenital myopathies. Neuromuscul. Disord. 2014, 24, 97-116. [CrossRef] [PubMed]

2. Kaplan, J.C. The 2012 version of the gene table of monogenic neuromuscular disorders. Neuromuscul. Disord. 2011, $21,833-861$. [CrossRef] [PubMed]

3. Ravenscroft, G.; Laing, N.G.; Bonnemann, C.G. Pathophysiological concepts in the congenital myopathies: Blurring the boundaries, sharpening the focus. Brain 2015, 138, 246-268. [CrossRef] [PubMed]

4. Cassandrini, D.; Trovato, R.; Rubegni, A.; Lenzi, S.; Fiorillo, C.; Baldacci, J.; Minetti, C.; Astrea, G.; Bruno, C.; Santorelli, F.M.; et al. Congenital myopathies: Clinical phenotypes and new diagnostic tools. Ital. J. Pediatr. 2017, 43, 101. [CrossRef] [PubMed]

5. Mah, J.K.; Joseph, J.T. An Overview of Congenital Myopathies. Continuum 2016, 22, 1932-1953. [CrossRef]

6. Jungbluth, H.; Treves, S.; Zorzato, F.; Sarkozy, A.; Ochala, J.; Sewry, C.; Phadke, R.; Gautel, M.; Muntoni, F. Congenital myopathies: Disorders of excitation-contraction coupling and muscle contraction. Nat. Rev. Neurol. 2018, 14, 151-167. [CrossRef]

7. Holterman, C.E.; Le Grand, F.; Kuang, S.; Seale, P.; Rudnicki, M.A. Megf10 regulates the progression of the satellite cell myogenic program. J. Cell Biol. 2007, 179, 911-922. [CrossRef]

8. Logan, C.V.; Lucke, B.; Pottinger, C.; Abdelhamed, Z.A.; Parry, D.A.; Szymanska, K.; Diggle, C.P.; van Riesen, A.; Morgan, J.E.; Markham, G.; et al. Mutations in MEGF10, a regulator of satellite cell myogenesis, cause early onset myopathy, areflexia, respiratory distress and dysphagia (EMARDD). Nat. Genet. 2011, 43, 1189-1192. [CrossRef]

9. Boyden, S.E.; Mahoney, L.J.; Kawahara, G.; Myers, J.A.; Mitsuhashi, S.; Estrella, E.A.; Duncan, A.R.; Dey, F.; DeChene, E.T.; Blasko-Goehringer, J.M.; et al. Mutations in the satellite cell gene MEGF10 cause a recessive congenital myopathy with minicores. Neurogenetics 2012, 13, 115-124. [CrossRef]

10. Gonorazky, H.D.; Bonnemann, C.G.; Dowling, J.J. The genetics of congenital myopathies. Handb. Clin. Neurol. 2018, 148, 549-564. [CrossRef]

11. Tadmouri, G.O.; Nair, P.; Obeid, T.; Al Ali, M.T.; Al Khaja, N.; Hamamy, H.A. Consanguinity and reproductive health among Arabs. Reprod. Health 2009, 6, 17. [CrossRef] [PubMed]

12. Liewluck, T.; Milone, M.; Tian, X.; Engel, A.G.; Staff, N.P.; Wong, L.J. Adult-onset respiratory insufficiency, scoliosis, and distal joint hyperlaxity in patients with multiminicore disease due to novel Megf10 mutations. Muscle Nerve 2016, 53, 984-988. [CrossRef] [PubMed]

13. Takayama, K.; Mitsuhashi, S.; Shin, J.Y.; Tanaka, R.; Fujii, T.; Tsuburaya, R.; Mukaida, S.; Noguchi, S.; Nonaka, I.; Nishino, I. Japanese multiple epidermal growth factor 10 (MEGF10) myopathy with novel mutations: A phenotype-genotype correlation. Neuromuscul. Disord. 2016, 26, 604-609. [CrossRef] [PubMed]

14. Harris, E.; Marini-Bettolo, C.; Topf, A.; Barresi, R.; Polvikoski, T.; Bailey, G.; Charlton, R.; Tellez, J.; MacArthur, D.; Guglieri, M.; et al. MEGF10 related myopathies: A new case with adult onset disease with prominent respiratory failure and review of reported phenotypes. Neuromuscul. Disord. 2018, 28, 48-53. [CrossRef]

15. Harris, E.; Topf, A.; Barresi, R.; Hudson, J.; Powell, H.; Tellez, J.; Hicks, D.; Porter, A.; Bertoli, M.; Evangelista, T.; et al. Exome sequences versus sequential gene testing in the UK highly specialised Service for Limb Girdle Muscular Dystrophy. Orphanet. J. Rare Dis. 2017, 12, 151. [CrossRef]

16. Wu, L.; Brady, L.; Shoffner, J.; Tarnopolsky, M.A. Next-generation sequencing to diagnose muscular dystrophy, rhabdomyolysis, and hyperCKemia. Can. J. Neurol. Sci. 2018, 45, 262-268. [CrossRef]

17. Fonseca, A.C.; Bonaldi, A.; Fonseca, S.A.; Otto, P.A.; Kok, F.; Bak, M.; Tommerup, N.; Vianna-Morgante, A.M. The segregation of different submicroscopic imbalances underlying the clinical variability associated with a familial karyotypically balanced translocation. Mol. Cytogenet. 2015, 8, 106. [CrossRef] [PubMed]

18. Mitsuhashi, S.; Mitsuhashi, H.; Alexander, M.S.; Sugimoto, H.; Kang, P.B. Cysteine mutations cause defective tyrosine phosphorylation in MEGF10 myopathy. FEBS Lett. 2013, 587, 2952-2957. [CrossRef]

19. Saha, M.; Mitsuhashi, S.; Jones, M.D.; Manko, K.; Reddy, H.M.; Bruels, C.C.; Cho, K.A.; Pacak, C.A.; Draper, I.; Kang, P.B. Consequences of MEGF10 deficiency on myoblast function and Notch1 interactions. Hum. Mol. Genet. 2017, 26, $2984-3000$. [CrossRef]

20. Pierson, T.M.; Markello, T.; Accardi, J.; Wolfe, L.; Adams, D.; Sincan, M.; Tarazi, N.M.; Fajardo, K.F.; Cherukuri, P.F.; Bajraktari, I.; et al. Novel SNP array analysis and exome sequencing detect a homozygous exon 7 deletion of MEGF10 causing early onset myopathy, areflexia, respiratory distress and dysphagia (EMARDD). Neuromuscul. Disord. 2013, 23, 483-488. [CrossRef]

21. Takayama, K.; Mitsuhashi, S.; Noguchi, S.; Hayashi, Y.; Nonaka, I.; Nishino, I. GP 155: A first Asian MEGF10 myopathy due to novel homozygous mutation. Neuromuscul. Disord. 2014, 24, 848. [CrossRef]

22. Posey, J.E.; Harel, T.; Liu, P.; Rosenfeld, J.A.; James, R.A.; Coban Akdemir, Z.H.; Walkiewicz, M.; Bi, W.; Xiao, R.; Ding, Y.; et al. Resolution of Disease Phenotypes Resulting from Multilocus Genomic Variation. N. Engl. J. Med. 2017, 376, 21-31. [CrossRef]

23. Alabdullatif, M.A.; Al Dhaibani, M.A.; Khassawneh, M.Y.; El-Hattab, A.W. Chromosomal microarray in a highly consanguineous population: Diagnostic yield, utility of regions of homozygosity, and novel mutations. Clin. Genet. 2017, 91, 616-622. [CrossRef]

24. Saha, M.; Rizzo, S.A.; Ramanathan, M.; Hightower, R.M.; Santostefano, K.E.; Terada, N.; Finkel, R.S.; Berg, J.S.; Chahin, N.; Pacak, C.A.; et al. Selective serotonin reuptake inhibitors ameliorate MEGF10 myopathy. Hum. Mol. Genet. 2019, 28, $2365-2377$. [CrossRef] [PubMed] 
25. Saladini, M.; Nizzardo, M.; Govoni, A.; Taiana, M.; Bresolin, N.; Comi, G.P.; Corti, S. Spinal muscular atrophy with respiratory distress type 1: Clinical phenotypes, molecular pathogenesis and therapeutic insights. J. Cell Mol. Med. 2020, 24, 1169-1178. [CrossRef] [PubMed]

26. Breivik, N.; Fiskerstrand, T.; Sand, T.; Vogt, C. Three siblings with progressive respiratory distress as infants. Tidsskr. Nor. Laegeforen. 2013, 133, 1459-1463. [CrossRef]

27. Arts, W.F.; de Groot, C.J. Congenital nemaline myopathy: Two patients with consanguineous parents, one with a progressive course. J. Neurol. 1983, 230, 123-130. [CrossRef] 